\title{
sciendo
}

\section{COMPARATIVE HISTOLOGICAL ANALYSIS OF INTESTINES OF LOACH, GRASS CARP AND CATFISH PROVIDE INSIGHTS INTO ADAPTIVE CHARACTERISTICS IN AIR-BREATHING FISH}

\author{
Longfei Huang ${ }^{1}$, Lijuan Yang ${ }^{1}$, Jianfang Liư ${ }^{3}$, Xiaojuan Cao ${ }^{1,2^{*}}$
}

${ }^{1}$ College of Fisheries, Key Lab of Agricultural Animal Genetics, Breeding and Reproduction of Ministry of Education/Key Lab of Freshwater Animal Breeding, Ministry of Agriculture, Huazhong Agricultural University, Wuhan 437000, Hubei, People's Republic of China

${ }^{2}$ Hubei Provincial Engineering Laboratory for Pond Aquaculture, Hubei, People's Republic of China

${ }^{3}$ Lishui University, Lishui 323000, Zhejiang, People's Republic of China

*Corresponding Author, Email: caoxiaojuan@mail.hzau.edu.cn

\section{ARTICLE INFO}

Received: 19 April 2020

Accepted: 13 May 2020

\section{Keywords:}

Air-breathing Intestinal structures Misgurnus anguillicaudatus Ctenopharyngodon idellus Pelteobagrus fulvidraco

\section{ABSTRACT}

Accessory respiratory is generally accepted to have evolved independently on numerous occasions in adaption to aquatic hypoxia in freshwater habitats. In general, the air-breathing organ in fish is believed to be structurally modified to supplement respiration. In this study, intuitive evidence for elaborate structural modifications of the intestine, an airbreathing organ in mud loach (Misgurnus anguillicaudatus), compared with two other obligate aquatic breathers, grass carp (Ctenopharyngodon idellus) and yellow catfish (Pelteobagrus fulvidraco), were directly provided by histological and morphometric methods. As a result, a sharply decreasing height of mucosal folds and thickness of muscularis were manifested in loach intestine from its anterior to posterior region. Compared with grass carp and yellow catfish, loach had the smallest ratios of mucosal fold height/muscularis thickness to intestinal lumen radius in the posterior intestine. These suggested that the posterior intestine is the air-breathing location for the loach. Furthermore, length density of capillary $(0.46 \pm 0.05$ $\mu \mathrm{m}^{-2}$ ) in the posterior intestine of the loach was significantly higher than those of grass carp and yellow catfish. Meanwhile, diffusion distance of air-blood barrier $(1.34 \pm 0.04 \mu \mathrm{m})$ in the posterior intestine of the loach was significantly smaller than those of the other two fish species. In summary, the characteristics of highly vascularized, short diffusion distance of airblood barrier, thinned and flattened made the posterior intestine a perfect air-breathing location for the loach.

Huang, L., Yang, L., Liu, J., Cao, X. (2020): Comparative histological analysis of intestines of loach, grass carp and catfish provide insights into adaptive characteristics in air-breathing fish. Croatian Journal of Fisheries, 78, 9198. DOI: 10.2478/cjf-2020-0009. 


\section{INTRODUCTION}

It is universally acknowledged that oxygen performs an exceptionally vital role for survival, growth, development and reproduction of bony fishes. The majority of fish are completely capable of satisfying continuously their aerobic demands from aquatic respiration with branchia. However, in response to some environmental or systemic factors, accessory respiration is stimulated in some fish species (Luiz et al., 2018; Giacomo et al., 2018). There are many different accessory respirational organs/tissues in fish, such as cutaneous layer, modified swim bladder, diverticula of the buccal, opercular or pharyngeal cavity, or alimentary tracts (Graham, 1997). Zhang et al. (2000) reported the specializations for terrestrial life in four species of oxudercine gobies mainly include the presence of dermal bulges, a thick middle cell layer and the vascularized epidermis. In addition, the pharynx of Asian swamp eel (Monopterus albus) was described short but complicated in structure, reflecting wrinkled pharyngeal wall and rather uneven surface interspersed holes, grooves and particles in different shapes among cells (Cao, 2008), which increased the contact area and improved the gas exchange. Although different bimodal breathers possess their respective air-breathing organs, they are believed to be structurally modified to supplement respiration.

Mud loach (Misgurnus anguillicaudatus), of the family Cobitidae, is a widespread, adaptable and weathersensitive demersal fish readily available in fresh market. As a representative facultative air-breather, mud loach is notable for its respiratory posterior intestine, which is described as histologically modified to suit its role of respiration for the deficient oxygen supply within the environment (Park et al., 2003; Goncalves et al., 2007; Nelson, 2014). Based on histological examination, the posterior intestine of loach is remarkably less suitable to alimentation absorption on account of the absence of typical characteristics of an absorptive intestina, containing the columnar epithelial cells with brush borders, thick muscular walls and an increased absorptive surface area through longitudinal folding (Jasiński, 1973; McMahon and Burggren, 1987).

Since the physiology of air-breathing in fishes is a fascinating topic (Graham, 1997), a considerable part of previous researches on fishes with bimodal respiration have been carried out, however, there were scarce issues concerned with histological comparison between bimodal breathers and aquatic breathers, offering intuitive prominences of the respiratory adaptations. As a novel perspective in this study, mud loach was specially chosen as a bimodal breather, compared with two aquatic breathers, namely grass carp (Ctenopharyngodon idellus) and yellow catfish (Pelteobagrus fulvidraco), in terms of intestinal histology, and its dedicated characteristics of intestine modified for accessory respiration were discussed simultaneously.

\section{MATERIALS AND METHODS}

\section{Ethics statement}

This study was conducted in strict accordance with the recommendations in the Guide for the Care and Use of Laboratory Animals of Huazhong Agricultural University. All handling procedures were made to minimize suffering of the animals. Tissue samples were collected after euthanasia with an overdose of MS 222.

\section{Sampling and paraffin slicing}

Mud loach, grass carp and yellow catfish were all captured in Yezhi lake located in Wuhan City, China. After anaesthesia, the fish ( $n=15,5$ for each kind of fish species) were weighed and their body lengths were measured (Table 1). And then, intestines of the three fish species were dissected. Delicate morphology of the intestines was investigated. In terms of the attributes of the thickness of the wall, caliber of the cavity, and transparency, the intestine of each fish species was divided into three parts (anterior intestine (Al), middle intestine (MI) and posterior intestine (PI)). The anterior, middle and posterior intestines of the three fish species were fixed in $10 \%$ neutral buffered formaldehyde at $4^{\circ} \mathrm{C}$ for $24 \mathrm{~h}$. The tissues were then dehydrated in increasing concentrations of ethanol series from $30 \%$ to $100 \%$, cleared in xylene, immersed and embedded in paraffin with an embedding machine (YD-6L, Jinhua, China). After cooling into gelosis on the freezing stage (YD-6L), the tissue blocks were sectioned at $7 \mu \mathrm{m}$ thickness by using a rotary microtome (YD-315). Subsequently, rather sound sections were undergoing a process of stretching and stoving with slices taken advantage of the Water BathSlide Drier (YD-AB).

\section{Staining}

The drying sections were treated with xylene, graded ethanol in decreasing concentration and dionized water, then stained with Servicebio's Haematoxylin and counterstained with Eosin $\mathrm{Y}(\mathrm{HE})$, followed by dehydrating through hierarchical ethanol, clearing in xylene and mounting under coverslips in neutral resin. Alkaline phosphatase (AP) staining was performed by reference to Shao et al. (2004).

\section{Measurements}

Photographic images were captured by using an Olympus microscope SZX7 accompanied with a camera Olympus DP74 (Tokyo, Japan) and a computer equipped with a measuring application (cellSens standard software). Here, mucosal fold height and muscular thickness of intestine were measured firstly. Then the radii of posterior intestine in the three fish species were estimated with aid of graphical fitting. The ratio of mucosal fold height 
Table 1. Anatomical measurement of three fish species $(n=15)$

\begin{tabular}{lcccc}
\hline \hline Species & Body length/mm & Wet Weight/g & Intestine length/mm & Intestinal ratio* \\
\hline Mud loach & $86.77 \pm 1.81$ & $5.40 \pm 0.51$ & $49.03 \pm 3.93$ & $0.56 \pm 0.03$ \\
Grass carp & $141.72 \pm 13.6$ & $62.16 \pm 5.65$ & $151.55 \pm 9.07$ & $1.07 \pm 0.04$ \\
Yellow catfish & $173.95 \pm 11.67$ & $86.75 \pm 12.85$ & $111.53 \pm 14.94$ & $0.64 \pm 0.05$ \\
\hline \hline
\end{tabular}

* Intestinal ratio signifies the ratio between intestinal length and body length

to posterior intestine radius and the ratio of muscular thickness to posterior intestine radius were further calculated. The four histological parameters above were measured based on transverse sections staining HE. While, calculations of two air-breathing indicators, namely the airblood diffusion distance (Zhang, et al., 2003) and capillary length densities (Shao, et al., 2004), were performed on sections dyed with AP. In details, the minimum distance from the capillary to intestinal epithelium was defined as the air-blood diffusion distance, and capillary length densities referred to capillary quantity per planar distance, of which computation was the ratio of double numbers of intestinal mucosa capillary endothelial cells to the area of a given view. Notably, all direct measurement stemmed from nine diverse microscopic visions chosen randomly from each sample section under three parallels.

\section{Statistical analysis}

Data were expressed as mean \pm SEM. All data were subjected to one-way ANOVA with LSD post hoc test using SPSS 23.0 (SPSS 23.0, Michigan Avenue, Chicago, IL, USA). $p<0.05$ was considered statistically significant.

\section{RESULTS}

\section{The comparisons of intestinal anatomy and morphology of the three fish species}

Fig. 1 shows mud loach, grass carp, yellow catfish and their intestine, including the $\mathrm{Al}, \mathrm{MI}$ and $\mathrm{PI}$. It was vividly depicted that in mud loach (Fig. 1d) the diameter of PI was much smaller than that of $\mathrm{Al}$ and $\mathrm{MI}$, and the peritubular capillary was very abundant in the PI. There was a trend towards thinness and translucence along the intestine in the three fish species.

Fig. 2 shows the histological structures of intestinal tracts in the three fish species. Obviously, there was distinct differentiation between mucosal fold transition among the three intestinal portions of mud loach at first examination and other two fish species. Epithelia of the Al and MI in mud loach comprised a single layer of columnar cells with numerous globe cells in a marginal arrangement, as pointed by black arrows (Fig. 2a,b), while less globe cells but considerable capillaries filled with erythrocytes, as indicated by white arrows, were observed in the squamous epithelium of PI (Fig. 2c).

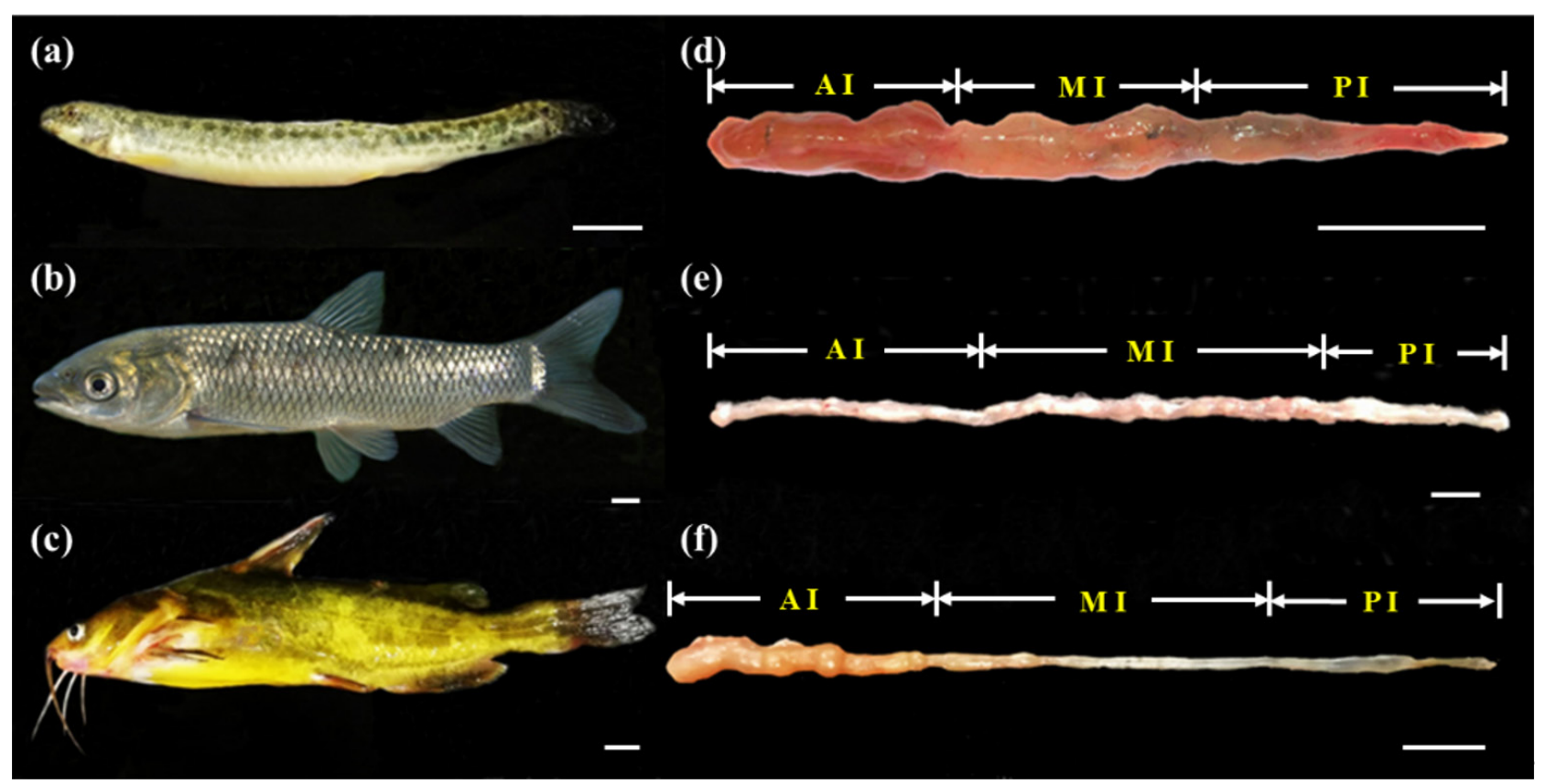

Fig 1. Morphology of mud loach, grass carp and yellow catfish, and the anatomical observation and their intestinal tracts. (a-c) The lateral views of mud loach, grass carp and yellow catfish; (d-f) the entire intestinal tracts of the loach, carp and catfish. The intestines are all partitioned into three different regions, namely anterior intestine (Al), middle intestine (MI) and posterior intestine (PI). Bar $=1 \mathrm{~cm}$ 


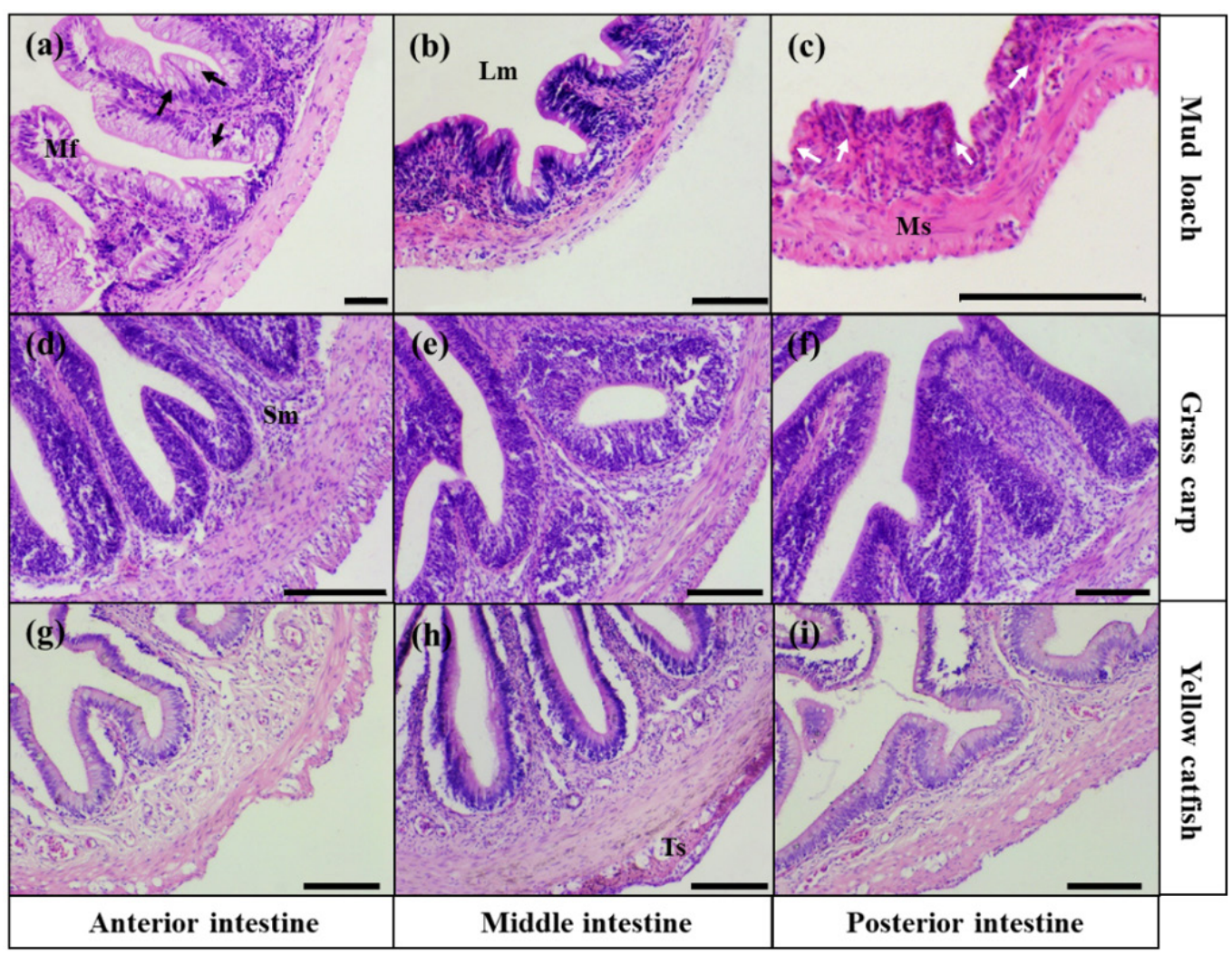

Fig 2. Histological observations of intestinal transverse sections stained by HE of the three fish species. (a-c) Anteriormiddle- and posterior- intestine of mud loach. Black arrows illustrate globe cells bordered in the epithelium and white arrows indicate capillaries with erythrocytes. (d-f) Anterior- middle- and posterior- intestine of grass carp. (g-i) Anteriormiddle- and posterior- intestine of yellow catfish. Mf, mucosal folds; Lm, lumen; Ms, muscularis; Sm, submucosa; Se, tunica serous. Bar $=10 \mu \mathrm{m}$

\section{Comparisons of histological parameters among the three fish species}

In the three fish species, significant declines of mucosal fold height were found along the intestinal tract from Al to PI (Fig. 3a), while the muscular thickness became significantly thinner from $\mathrm{Al}$ to $\mathrm{PI}$ in mud loach and yellow catfish (Fig. 3b). Fig. $3 c$ and $3 d$ respectively show that the ratio of mucosal fold height to posterior intestine radius and the ratio of muscular thickness to posterior intestine radius in mud loach were obviously smaller than those of the other two aquatic breathers, grass carp and yellow catfish.

\section{Comparison of two air-breathing indicators of three species}

It is generally acknowledged that the air-breathing organs in fish are highly vascularized. Fig. 4 shows capillary length densities and air-blood diffusion distances in three intestinal portions of the three fish species. There was no significant difference in capillary length density in $\mathrm{Al}$ between mud loach and grass carp (Fig. 4a). Yellow catfish presented the lowest air-blood diffusion distance in Al.
There was no significant difference in the diffusion distance in MI between mud loach and yellow catfish. When it came to the two indicators for accessory respiration, the length density of capillary vessels and diffusion distance of airblood barrier of PI in mud loach, respectively highest of $0.46 \pm 0.05 \mu \mathrm{m}^{-2}$ and lowest of $1.34 \pm 0.04 \mu \mathrm{m}$, both signified prominent difference from those of grass carp and yellow catfish (Fig. 4a,b).

\section{DISCUSSION}

A paralogous comparison of intestinal structures was firstly performed between a facultative air-breather (mud loach) and two aquatic breathers (grass carp and yellow catfish) here, to provide intuitive evidences for elaborate structural modifications of air-breathing organs. Even these three fish species share little in taxonomy and feeding habit, they have similar habitat settings, namely middle and demersal layer, and their intestines are all reported to partition into three portions (McMahon and Burggren, 1987; Ye et al., 2003; Cao and Wang, 2009). 
(a)

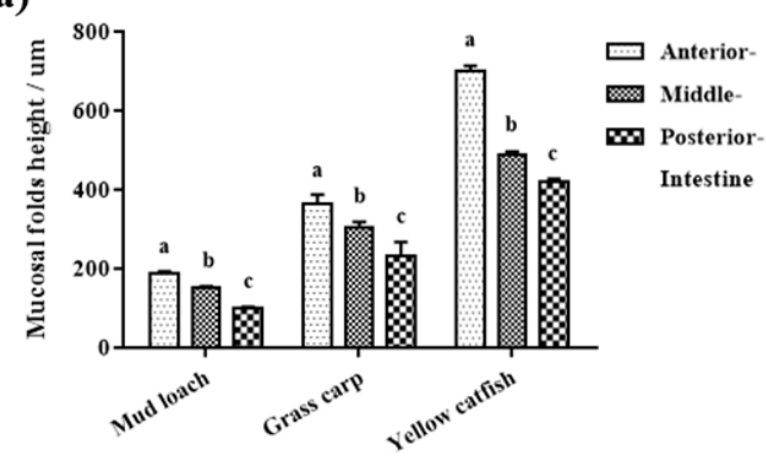

(c)

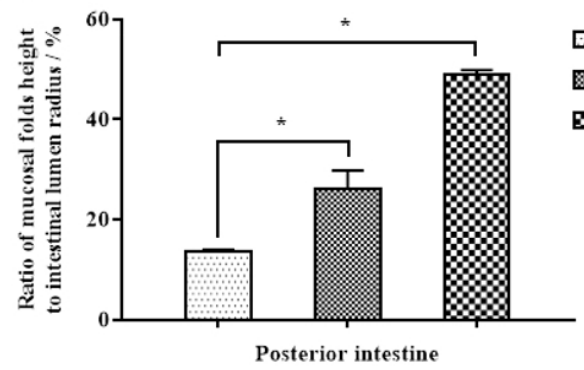

(b)

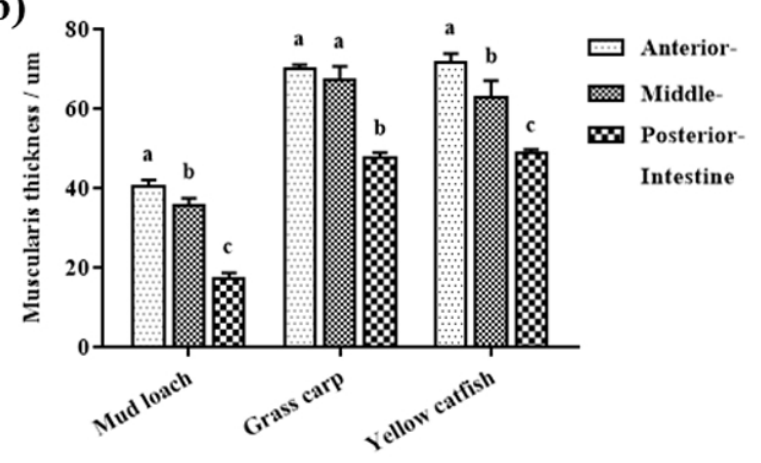

(d)

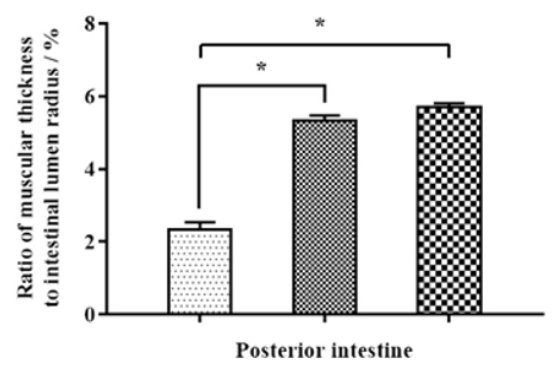

Mud loach

Grass carp

Yellow catfish

Fig 3. Comparisons of the height of mucosal folds and the thickness of the muscular layer in intestine tracts among mud loach, grass carp and yellow catfish. (a) Comparisons of mucosal fold height of three intestinal portions among the three species. (b) Comparisons of muscular thickness of three intestinal portions among the three species. (c) Comparison of the ratios of mucosal fold height to posterior intestine radius among the three species. (d) Comparison of the ratios of muscular thickness to posterior intestine radius among the three species. Different letters and asterisks upon the column are representing a significant difference between species $(p<0.05)$

(a)

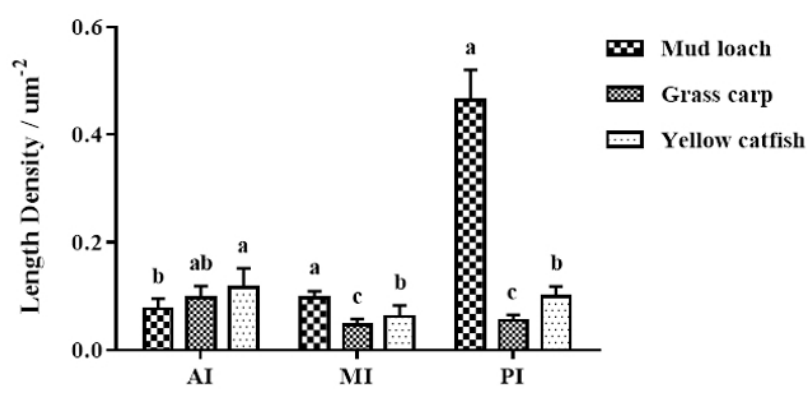

(b)

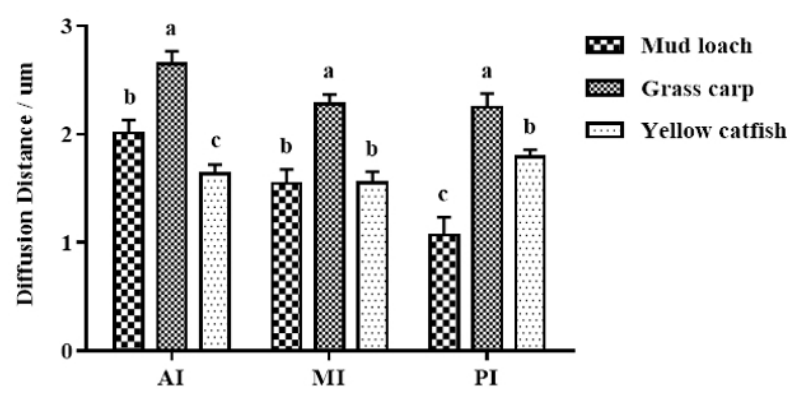

Fig 4. Comparisons of capillary length densities and air-blood diffusion distances of intestinal tracts among the three fish species. (a) Comparisons of capillary length densities of anterior intestine (AI), middle intestine (MI) and posterior intestine (PI) among the three fish species. (b) Comparisons of air-blood diffusion distances of $\mathrm{Al}, \mathrm{MI}$ and $\mathrm{PI}$ among the three fish species. Different letters upon the column are representing a significant difference between species $(p<0.05)$

Therefore, intestines of sympatric grass carp and yellow carp were used to compare with the intestine (an airbreathing organ) of mud loach in this study.

It had been examined that more flattened mucosal folds and thinner intestinal muscle layer in PI of the facultative air-breather mud loach, significantly different from the other two aquatic breathers, implied its specific alternative function other than digestion and absorption. Moreover, finger-like mucosal folds stretched out of submucosa were emerged both in $\mathrm{Al}$ and $\mathrm{MI}$, but replaced by squamous epithelium in $\mathrm{PI}$ of loach, in agreement with the respiratory intestine of bronze Corydoras Corydoras aeneus (Leszek et al., 2017). Goncalves et al. (2007) also reported that mucosa of PI in loach was embedded with intraepithelial capillaries, as well as erythrocytes in an elaborate arrangement, rather beneficial for gas exchange, which was authenticated in our results. All these dedicate alteration of $\mathrm{PI}$ in mud loach above mentioned and provided an opportune adaption for air-breathing. 
Indeed, plentiful air-breathing fish species share some histological characteristics of accessory respiration organs in common. For instance, the PI of Neotropical catfish, $C$. paleatus, is described well vascularized with capillaries between epithelial cells (Plaul et al., 2016). Likewise, the penetration of an elaborate capillary bed into the epithelium was the primary transformation appeared in the respiratory intestine of Hoplosternum thoracatum, accompanied by a sharp decrease in mucosa epithelial thickness (Huebner and Chee 1978; Yadav, 1980). In addition, the organization of the stomach corpus was presented especial, and the epithelial cells of which located in the capillary mesh while flattened extensions covered the adjacent capillaries, according to the report from Satora in 1998. Thus, the air-breathing function of fish air-breathing organ primarily lies in its vascularized surface based on histological structure, and the degree of capillarity is mainly manifested in two indicators: capillary density and diffusion distance (Graham, 1997). Capillary vessels of air-breathing fish are abundantly distributed in the epithelium of the air-breathing organ, which reduces the diffusion distance of the air-blood barrier and enhances the function of gas exchange (Jiang and Pan, 2012). The length density of capillary vessels of $\mathrm{PI}$ in mud loach was significantly larger than that of grass carp and yellow catfish, while the diffusion distance of air-blood barrier in mud loach showed prominent smaller, supporting a further proof for the respiratory function of loach PI. Interestingly, the diffusion distance of $\mathrm{PI}$ in mud loach approached that of the air-breathing opercular chamber in Boleophthalmus boddaerti (Niva et al., 1981, Table 2). More amazingly, Hughes and Singh (1970) discovered that the diffusion distance of the airblood barrier was as tiny as $1 \mu \mathrm{m}$ in Anabas testudineus, gigantically satisfying the demand of air-breathing.

In summary, it is considered that epithelium of airbreathing organ in fish tends to be specialized in flattening and deep vascularization, implying short diffusion distance of air-blood barrier and rich capillary density, which immensely accommodates to accessory respiration in turn. The formation of abundant capillaries in the accessory respiratory organs of fish plays a vital role in guaranteeing the normal performance of air-breathing. In future, the molecular regulation mechanism of fish airbreathing remains to be examined systemically.

\section{ACKNOWLEDGEMENTS}

This study was financially supported by Research on the Industry Development of Rice-fish Symbiosis from the Perspective of Whole Industry Chain (Project Number: 2019GYX18).

\section{SAŽETAK}

\section{USPOREDBA HISTOLOŠKE ANALIZE CRIJEVA VI- JUNA, AMURA I SOMA, PRUŽA UVID U ADAP- TIVNE KARAKTERISTIKE RIBA KOJE UDIŠU ZRAK}

Table 2. Selected diffusion distances of air-blood barrier and capillary densities in the purported respiratory epithelium of some air-breathing fishes with different air-breathing organs (complement for Nelson, 2014)

\begin{tabular}{|c|c|c|c|c|}
\hline $\begin{array}{l}\text { Species } \\
\text { (Latin name) }\end{array}$ & $\begin{array}{l}\text { Air-breathing } \\
\text { Organs (ABO) }\end{array}$ & $\begin{array}{c}\text { Diffusion } \\
\text { distance } / \mu \mathrm{m}\end{array}$ & $\begin{array}{c}\text { Capillary } \\
\text { density } / \mu \mathrm{m}^{-2}\end{array}$ & $\begin{array}{c}\text { Source } \\
\text { cited }\end{array}$ \\
\hline Boleophthalmus boddaerti & Opercular chamber & 1.22 & & Niva et al., 1981 \\
\hline Heteropneustes fossilis & Air-sac & 1.6 & & Munshi et al., 1986 \\
\hline Anabas testudineus & Supra-branchial chamber & 0.21 & & Hughes and Singh, 1970 \\
\hline Channa punctata & Supra-branchial chamber & 0.78 & & Hakim et al., 1978 \\
\hline Periophthalmus cantonensis & Skin & 9 & & Tamura et al., 1976 \\
\hline Boleophthalmus pectinirostris & Skin & $5.5 \sim 44.3$ & & Zhang et al., 2000 \\
\hline Dallia pectoralis & Oesophagus & $<1$ & & Crawford, 1974 \\
\hline Ancistrus multispinis & Stomach & 0.6 & 0.07 & Satora, 1998 \\
\hline Pterygoplichthys anisitsi & Stomach & $0.40 \sim 0.74$ & & Cruz et al.,2009 \\
\hline Hoplosternum thoracatum & Intestine & $1 \sim 2$ & & Huebner and Chee, 1978 \\
\hline Lepidocephalichthys gun-tea & Intestine & $0.86 \sim 1.08$ & 0.15 & Yadav and Singh, 1980 \\
\hline Paramisgurnus dabryanus & Intestine & $1.95 \pm 0.34$ & & Liu and Wang, 2017 \\
\hline Misgurnus anguillicaudatus & Intestine & $1.34 \pm 0.04$ & $0.46 \pm 0.05$ & This study \\
\hline
\end{tabular}


Općenito je prihvaćeno da su pomoćni dišni organi riba u više navrata samostalno evoluirali pri prilagođavanju slatkovodnim staništima i vodenoj hipoksiji. Vjeruje se da je organ za udisanje zraka kod riba strukturno modificiran kako bi nadopunio respiraciju. $U$ ovom istraživanju prezentirani su intuitivni dokazi detaljne strukturne modifikacije crijeva i organa za udisanje zraka kod muljnog vijuna (Misgurnus anguillicaudatus), uspoređujući ih amurom (Ctenopharyngodon idellus) i žutim somom (Pelteobagrus fulvidraco). izravno dobiveni histološkom i morfometrijskom metodom. Kod muljnog vijuna očitovala se naglo smanjena visina nabora sluznice i debljina mišićnog sloja od prednjeg do stražnjeg dijela crijeva. $\mathrm{U}$ usporedbi sa amurom i žutim somom, vijun je imao i najmanji omjer visine nabora sluznice/debljine mišićnog sloja i polumjera crijeva u stražnjem dijelu crijevu. To sugerira da je moguće stražnji dio crijeva lokacija na kojoj vijun udiše zrak. Nadalje, gustoća kapilara $(0,46 \pm 0,05$ $\mu \mathrm{m}^{-2}$ ) u zadnjem crijevu vijuna bila je značajno viša od amura i žutog soma. Također, difuzijska udaljenost zračnokrvne barijere $(1,34 \pm 0,04 \mu \mathrm{m})$ u stražnjem crijevu vijuna bila je značajno manja od one $u$ druge dvije vrste riba. Ukratko, karakteristike poput visoke prokrvljenosti, kratke udaljenosti difuzije zračno-krvne barijere, prorijeđenosti i spljoštenosti, učinile su stražnji dio crijeva savršenom lokacijom za udisanje zraka istraživane vrste vijuna.

Ključne riječi: Udisanje zraka, crijevne strukture, Misgurnus anguillicaudatus, Ctenopharyngodon idellus, Pelteobagrus fulvidraco

\section{REFERENCES}

Cao, S. D. (2008): A scanning electron microscopical study on pharynx surface of Monopterus anus. Sichuan Journal of Zoology, 27, 858-859.

Cao, X. J., Wang, W. M. (2009): Histology and mucin histochemistry of the digestive tract of yellow catfish, Pelteobagrus fulvidraco. Anatomia Histologia Embryologia, 38, 254-261.

Crawford, R. H. (1974): Structure of an air-breathing organ and the swim bladder in the Alaska blackfish, Dallia pectoralis Bean. Canadian Journal of Zoology, 52, 12211225.

Cruz, D., Luis, A., Pedretti, A. C. E., Fernandes, M. N. (2009): Stereological estimation of the surface area and oxygen diffusing capacity of the respiratory stomach of the air breathing armored catfish Pterygoplichthys anisitsi (Teleostei: Loricariidae). Journal of Morphology, 270, 601-614.

Giacomo, Z. E., Rita, L., Gioele, C., Michal, K. (2018): Airbreathing in fish: Air- breathing organs and control of respiration: Nerves and neurotransmitters in the airbreathing organs and the skin. Acta Histochemica, 120, 630-641.

Goncalves, A. F., Castro, L. F. C., Pereira-Wilson, C., Coimbra, J., Wilson, J. M. (2007): Is there a compromise between nutrient uptake and gas exchange in the gut of Misgurnus anguillicaudatus, an intestinal air-breathing fish? Comparative Biochemistry and Physiology Part D Genomics and Proteomics, 2, 0-355.

Graham, J. B. (1997): Air Breathing Fishes: Evolution, Diversity and Adaptation. Academic Press, San Diego, USA. 299.

Hakim, A., Munshi, J. S. D., Hughes, G. M. (1978): Morphometries of the respiratory organs of the Indian green snake-headed fish, Channa punctate. Journal of Zoology, 184, 519-543.

Huebner, E., Chee, G. (1978): Histological and ultrastructural specialization of the digestive tract of the intestinal air breather Hoplosternum thoracatum (teleost). Journal of Morphology, 157, 301-327.

Hughes, G. M., Singh, B. N. (1970): Respiration in an airbreathing fish, the climbing perch Anabas testudineus Bloch. Journal of Experimental Biology, 53, 265-280.

Jasiński, A. (1973): Air-blood barrier in the respiratory intestine of the pond-loach, Misgurmus fossilis L. Acta Anatomica, 86, 376.

Kariya, T., Hotta, H., Takahashi, M. (1969): Relation between the condition of the stomach mucous folds and the stomach content in the mackerel. Bulletin of the Japanese Society of Scientific Fisheries, 35, 441445.

Liu, Y. Q., Wang, Z. J. (2017): A study on structural characteristics of intestinal tract of the air-breathing loach, Paramisgurnus dabryanus (Sauvage, 1878). Pakistan Journal of Zoology, 49, 1223-1230.

Luiz, H. F., Vinicius, A. A., David, J. M., Francisco, T. R. (2018): Control of air-breathing in fishes: Central and peripheral receptors. Acta Histochemica, 120, 542-653.

McMahon, B. R., Burggren, W. W. (1987): Respiratory physiology of intestinal air breathing in the teleost fish Misgurnus anguillicaudatus. Journal of Experimental Biology, 133, 371-393.

Munshi, J. S. D., Weibel, E. R., Gehr, P., Hughes, G. M. (1986): Structure of the respiratory air sac of Heteropneustes fossilis (Bloch) (Heteropneustidae pisces). Proceedings of the Indian National Science Academy Part B, 52, 703713.

Nelson, J. A. (2014): Breaking wind to survive: fishes that breathe air with their gut. Journal of Fish Biology, 84, 554-576.

Niva, B., Ojha, J., Munshi, J. S. D. (1981): Morphometrics of the respiratory organs of an estuarine goby, Boleophthalmus boddaerti. Japanese Journal of Ichthyology, 27, 316-326.

Park, J. Y., Kim, I. S., Kim, S. Y. (2003): Structure and mucous histochemistry of the intestinal respiratory tract of the mud loach, Misgurnus anguillicaudatus (cantor). Journal of Applied Ichthyology, 19, 5.

Plaul, S. E., Pastor, R., Alcira, O. D., Barbeito, C. G. (2016): Immunohistochemical and ultrastructural evidence of functional organization along the Corydoras paleatus intestine. Microscopy Research and Technique, 79, 
140-148.

Satora, L. (1998): Histological and ultrastructural study of the stomach of the air-breathing Ancistrus multispinnis (Siluriformes, Teleostei). Canadian Journal of Zoology, 76, 83-86.

Satora, L., Koziol, K., Zebrowski, J. (2017): Squamous epithelium formation in the respiratory intestine of the bronze Corydoras, Corydoras aeneus (Callichthyidae teleostei). Acta Histochemica, 119, 563-568.

Shao, L.J., Zhu, Q. X., Zeng, Y. F. (2004): Comparison of two methods of microvascular display. Chinese Journal of Anatomy, 27, 427-452.

Tamura, S. O., Morii, H., Yuzuriha, M. (1976): Respiration of the amphibious fishes Periophthalmus cantonensis and Boleophthalmus chinensis in water and on land. Journal of Experimental Biology, 65, 97-107.
Yadav, A. N., Singh, B. R. (1980): The gut of an intestinal airbreathing fish, Lepidocephalus guntea (Ham). Archives of Biology, 91, 413-422.

Ye, Y. T, Wang, Y. H., Lin, S. M., Luo, L. (2003): Transmural fluxes of ten essential ammo acids in intestinal gut of Ctehopharyhgodoh idellus in vitro. Journal of Fishery Sciences of China, 10, 311-316.

Zhang, J., Taniguchi, T., Takita, T., Ali, A. B. (2000): On the epidermal structure of Boteophthalmus and Scartelaos mudskippers with reference to their adaptation to terrestrial life. Ichthyological Research, 47, 359-366.

Zhang, J., Taniguchi, T., Takita, T., Ali, A. B. (2003): A study on the epidermal structure of Periophthalmodon and Periophthalmus mudskippers with reference to their terrestrial adaptation. Ichthyological Research, 50, 310-317. 